\title{
The E. Williams Site on Martin Creek in Panola County, Texas
}

Timothy K. Perttula

Heritage Research Center, Stephen F. Austin State University

Follow this and additional works at: https://scholarworks.sfasu.edu/ita

Part of the American Material Culture Commons, Archaeological Anthropology Commons, Environmental Studies Commons, Other American Studies Commons, Other Arts and Humanities Commons, Other History of Art, Architecture, and Archaeology Commons, and the United States History Commons

Tell us how this article helped you.

This Article is brought to you for free and open access by the Center for Regional Heritage Research at SFA ScholarWorks. It has been accepted for inclusion in Index of Texas Archaeology: Open Access Gray Literature from the Lone Star State by an authorized editor of SFA ScholarWorks. For more information, please contact cdsscholarworks@sfasu.edu. 


\section{The E. Williams Site on Martin Creek in Panola County, Texas \\ Creative Commons License \\ (c) $($ ) $(9)$}

This work is licensed under a Creative Commons Attribution-NonCommercial 4.0 International License 


\title{
The E. Williams Site on Martin Creek in Panola County, Texas
}

\author{
Timothy K. Perttula
}

\section{INTRODUCTION}

The E. Williams site is an ancestral Caddo site on the north side of Martin Creek, an eastward-flowing tributary to the Sabine River, in Panola County in the East Texas Pineywoods (Figure 1). The site is just a few miles west of the confluence of Martin Creek and the Sabine River. Buddy Calvin Jones located the site (which he labeled as Panola-2) and obtained a small collection of ceramic vessel sherds, probably from surface contexts. This collection is among the holdings of the Gregg County Historical Museum.

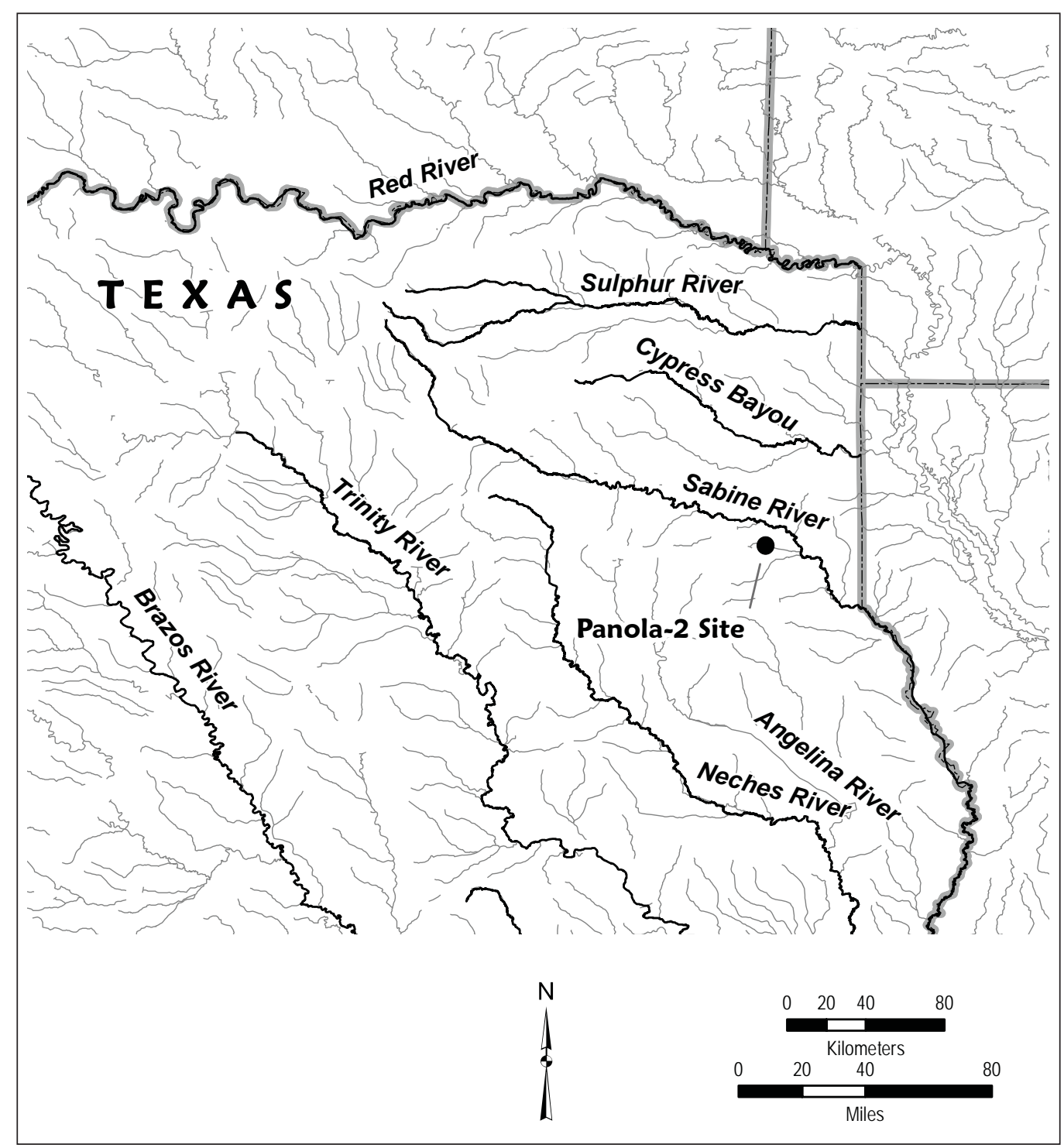

Figure 1. Location of the E. Williams site in East Texas. 


\section{Ceramic Sherd Assemblage}

There are 96 rim, body, and base sherds from grog-tempered vessels at the E. Williams site (Table 1). The 35 decorated sherds include those from both utility ware ( 85.7 percent) and fine ware (14.3 percent) vessels. More than 70 percent of the rims in the assemblage are also from utility wares, which also suggests that the manufacture and use of utility ware jars was an important part of the local Caddo ceramic tradition. The plain to decorated sherd ratio is 1.74 .

Table 1. Ceramic sherd assemblage from the E. Williams site in Panola County, Texas.

\begin{tabular}{llllll}
\hline Ware & Grog-tempered & Rim & Body & Base & N \\
\hline Plain & 61 & 1 & 54 & 6 & 61 \\
Utility & 30 & 5 & 25 & - & 30 \\
Fine & 5 & 1 & 4 & - & 5 \\
\hline Totals & 96 & 7 & 83 & 6 & 96 \\
\hline
\end{tabular}

The principal decorative methods represented in the utility wares from the E. Williams site are sherds from incised (42.9 percent of all the decorated sherds) and punctated (31.4 percent) vessels. Only one sherd (2.9 percent) is from a brushed vessel, and there are also several sherds decorated with incised-punctated elements ( 8.6 percent of all the decorated sherds, (Table 2). The fine ware sherds are from engraved carinated bowls and bottles.

Table 2. Decorated methods and decorative elements in the E. Williams site ceramic assemblage.

\begin{tabular}{|c|c|c|c|}
\hline $\begin{array}{l}\text { Decorative method/ } \\
\text { Decorative element }\end{array}$ & Rim & Body & $\mathrm{N}$ \\
\hline \multicolumn{4}{|l|}{ Utility Ware } \\
\hline \multicolumn{4}{|l|}{ Brushed } \\
\hline parallel brushed & - & 1 & 1 \\
\hline \multicolumn{4}{|l|}{ Incised } \\
\hline cross-hatched lines & 2 & 1 & 3 \\
\hline curvilinear lines & 1 & - & 1 \\
\hline parallel lines & - & 8 & 8 \\
\hline straight line & - & 3 & 3 \\
\hline \multicolumn{4}{|l|}{ Incised-Punctated } \\
\hline $\begin{array}{l}\text { diagonal incised panels filled with circular } \\
\text { punctations }\end{array}$ & 1 & - & 1 \\
\hline $\begin{array}{l}\text { parallel lines and adjacent fingernail } \\
\text { punctated zone }\end{array}$ & - & 1 & 1 \\
\hline $\begin{array}{l}\text { parallel lines and adjacent tool punctated } \\
\text { zone }\end{array}$ & - & 1 & 1 \\
\hline \multicolumn{4}{|l|}{ Punctated } \\
\hline fingernail punctated rows & - & 4 & 4 \\
\hline tool punctated rows & 1 & 6 & 7 \\
\hline Subtotal, Utility Ware & 5 & 25 & 30 \\
\hline
\end{tabular}


Table 2. Decorated methods and decorative elements in the E. Williams site ceramic assemblage, cont.

\begin{tabular}{llll}
\hline $\begin{array}{l}\text { Decorative method/ } \\
\text { Decorative element }\end{array}$ & Rim & Body & N \\
\hline Fine Ware & & 2 & 2 \\
$\begin{array}{l}\text { Engraved } \\
\text { curvilinear lines* } \\
\text { horizontal line }\end{array}$ - & - & 1 & 1 \\
spiral and concentric circle elements* & - & - & 1 \\
vertical and curvilinear lines & 1 & 4 & 5 \\
Subtotal, Fine Ware & 1 & 29 & 35 \\
\hline Totals & 6 & & 1
\end{tabular}

*=engraved bottle sherds

The one brushed body sherd is from a jar that has parallel brushing marks (see Table 2), likely oriented vertically on the vessel body. This may be from a Bullard Brushed jar. The very low proportion of brushed sherds in the decorated sherd assemblage suggests that the E. Williams site was occupied before brushed utility ware vessels became common in this part of the middle Sabine River basin. Analyses of decorated ceramic assemblages at the nearby Musgano site (41RK19, Perttula 2014) and the Murvaul Creek site (41PN175, Perttula 2015), along with radiocarbon dating of features from the sites (McKee et al. 2015; Perttula 2014), indicate that brushed ceramic vessels were not common in regional Caddo ceramic assemblages until after ca. A.D. $1250-1275$.

Incised vessel sherds are proportionally quite abundant in the E. Williams site ceramic assemblage. In addition to three cross-hatched incised rim sherds, probably from Dunkin Incised vessels, there is also an Early Caddo period Crockett Curvilinear Incised rim sherd with curvilinear incised lines (Figure 2a; see Suhm and Jelks 1962:Plate 17b, f-g, m). An incised-punctated rim sherd with diagonal panels filled with circular punctations (Figure 2b) is from an Early Caddo Pennington Punctated-Incised bowl (see Suhm and Jelks 1962:Plate 61b).

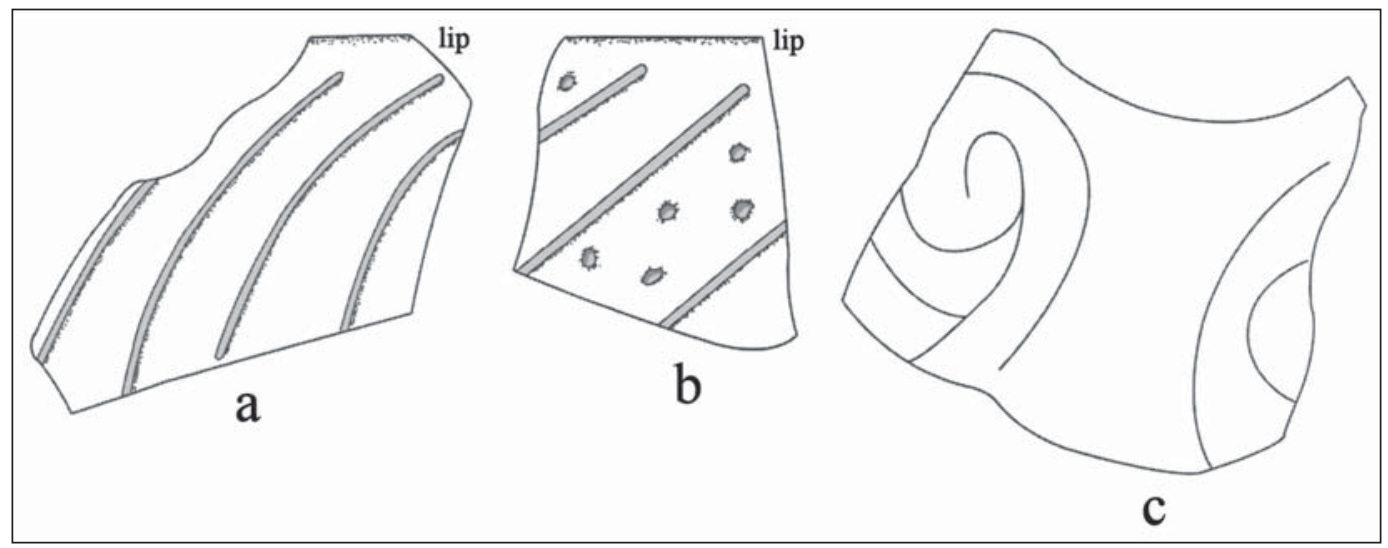

Figure 2. Selected decorative elements on utility ware and fine ware rim or body sherds from the E. Williams site: a, incised rim; b, incised-punctated rim; c, engraved bottle body sherd.

Sixty percent of the fine ware sherds are from bottles (see Table 2). Two body sherds have curvilinear engraved lines, while the other has engraved spiral and concentric circle elements (see Figure 2c). This bottle sherd is from a Holly Fine Engraved vessel (see Suhm and Jelks 1962:Plate 40e). One carinated bowl sherd has a horizontal engraved line above the carina; this may be from a Hickory Engraved vessel (see 
Suhm and Jelks 1962:Plate 36j). The other carinated bowl sherd has vertical and curvilinear engraved lines, and may also be from a Holly Fine Engraved vessel.

\section{SUMMARY AND CONCLUSIONS}

The E. Williams site is on Martin Creek in Panola County, not far west of the confluence of Martin Creek with the Sabine River. The site was located by Buddy Calvin Jones and he obtained a surface collection of plain and decorated sherds from it; this sherd assemblage ( $\mathrm{n}=96$ sherds) is in the collections of the Gregg County Historical Museum.

The ceramic assemblage includes sherds from grog-tempered plain ware, utility ware, and fine ware vessels. The near absence of brushed utility ware sherds in the decorated sherd assemblage, and the presence of Crockett Curvilinear Incised, Pennington Punctated-Incised, Holly Fine Engraved, and Hickory Engraved sherds, Early Caddo period (ca. A.D. 1000-1200) diagnostic artifacts, suggests that the E. Williams site likely was occupied by Caddo peoples sometime before ca. A.D. 1200-1250.

\section{ACKNOWLEDGMENTS}

I thank Patti Haskins of the Gregg County Historical Museum for the opportunity to analyze the ceramic sherds from the E. Williams site. Lance Trask prepared the figures for this article.

\section{REFERENCES CITED}

McKee, A., C. D. Frederick, T. K. Perttula, R. Z. Selden, L. Bush, L. Kemp, B. Gregory, C. Yost, L. S. Cummings,

J. R. Ferguson, M. D. Glascock, S. Tomka, L. Cecil, C. Masiello, X. Gao, C. Goodmaster, and V. Beasley

2015 Data Recovery Investigations: Murvaul Creek Site (41PN175), Panola County, Texas. Miscellaneous Reports of Investigations No. 598. Geo-Marine, Inc., Plano.

Perttula, T. K.

2014 The Caddo Archaeology of the Musgano Site (41RK19) in the Sabine River Basin of East Texas. Special Publication No. 28. Friends of Northeast Texas Archaeology, Pittsburg and Austin.

Perttula, T. K., with contributions from R. Z. Selden Jr.

2015 Aboriginal Ceramic Vessel and Pipe Sherds from the Murvaul Creek Site (41PN175). In Data Recovery Investigations: Murvaul Creek Site (41PN175), Panola County, Texas, by A. McKee, C. D. Frederick, T. K. Perttula, R. Z. Selden, L. Bush, L. Kemp, B. Gregory, C. Yost, L. S. Cummings, J. R. Ferguson, M. D. Glascock, S. Tomka, L. Cecil, C. Masiello, X. Gao, C. Goodmaster, and V. Beasley, pp. 105-186. Miscellaneous Reports of Investigations No. 598. Geo-Marine, Inc., Plano.

Suhm, D. A. and E. B. Jelks (editors)

1962 Handbook of Texas Archeology: Type Descriptions. Special Publication No. 1, Texas Archeological Society, and Bulletin No. 4, Texas Memorial Museum, Austin. Reprinted in 2009, Gustav's Library, Davenport, Iowa. 